САФОНОВА Наталия Вячеславовна - младший научный сотрудник Института востоковедения РАН (107031, Россия, г. Москва, ул. Рождественка, 12/1, cmp. 1; safonovanat@gmail.com)

\title{
ПРОБЛЕМА ИСЛАМИЗМА И ИСЛАМСКОГО ЭКСТРЕМИЗМА ВО ФРАНЦИИ
}

\begin{abstract}
Аннотация. Такие явления, как исламизм и исламский экстремизм, возникли во Франции относительно недавно. Хотя на территории страны проживают уже несколько поколений мусульманских мигрантов, именно в последнее время увеличилось число террористических атак со стороны исламских экстремистов. Больше всего актов насилия было совершено в 2010-х гг.: в отличие от предыдущих лет, в их организации участвовали не столько международные экстремистские движения, сколько французские граждане. Основные характеристики исламского экстремизма и комплекс связанных с ним проблем рассмотрены в рамках данной статьи.
\end{abstract}

Ключевые слова: исламизм, Франция, исламский экстремизм, радикальный ислам

И сламизм - относительно молодой термин ${ }^{1}$, который тесно связан с одной из характеристик ислама: с его «мирским» характером, что предполагает подробные указания экономического, политического и социального толка, по которым следует строить свою жизнь. Но чаще всего исламизм понимается как политическое явление. При этом однозначное определение исламизма или исламского экстремизма не существует.

Термины «исламизм», «исламский радикализм», «фундаментализм», «ваххабизм», «салафизм», «джихадизм» часто соседствуют и взаимозаменяют друг друга: «зачастую не может быть проведена четкая разделительная линия между фундаменталистами и традиционалистами, консерваторами и реформаторами» [Наумкин 2006: 6]. Важно, что экстремисты, в отличие от радикалов, используют террористические методы борьбы. Так, по мнению И.П. Добаева, исламский экстремизм - это крайняя форма исламского радикализма, которая имеет однозначно негативное содержание и подразумевает методы борьбы, выходящие за рамки законных [Добаев 2002: 55].

Во Франции такие явления, как исламизм и исламский экстремизм, появились относительно недавно и связаны с проживанием нескольких поколений мусульман-мигрантов ${ }^{2}$. Также недавно, а именно в годы президентства Ф. Олланда, на фоне террористических атак и принятия европейских антитеррористических норм получило распространение понятие радикализации.

Франция испытала на себе террористические атаки со стороны различных экстремистов: согласно глобальной базе террористических атак, во Франции действуют антихристианские, антисемитские и антимусульманские экстремисты, анархисты, радикальные борцы за права животных, Командование обороны французского народа и Родины, корсиканские националисты и т.д. и, наконец, мусульманские экстремисты и «экстремисты, вдохновленные джи-

1 Около 1970 г.

2 Согласно данным Евростата, во Франции проживает около 5,43 млн мусульман. Cм. Statistic explained. - Eurostat. 01.01.2020. URL: https://ec.europa.eu/eurostat/statistics-explained/index.php?title=File:Non-national_population_by_group_of_citizenship,_1_ January_2020.png\#filehistory (accessed 10.07.2021). 
хадистами». Но больше всего жертв и пострадавших было от атак исламских экстремистов. Чаще всего они нападают на полицейских и военных ${ }^{1}$.

Наибольшее число актов насилия исламские экстремисты совершили в 2010-х гг, причем если до этого на территории страны чаще орудовали международные экстремистские движения, то теперь совершать теракты стали уже французские граждане. Так, LeMonde привел следующие цифры: с середины 2014 по июль 2016 г. исламисты стали причиной 236 смертей во Франции ${ }^{2}$. За период с 2015 по 2018 г. 249 человек были убиты и 928 ранены в 22 террористических актах, совершенных исламскими экстремистами ${ }^{3}$.

Исламистских террористических организаций и группировок сегодня существует более десятка, большинство из них базируются на Ближнем Востоке и в Африке. При этом исламистский терроризм захлестнул многие страны Европы, которые благодаря большой численности проживающих там мусульман стали также рассматриваться как «земля ислама». Но, как отмечает французский политолог Тьерри Вольтон, единого центра и структуры у исламистских террористических организаций нет. Отдельные группировки существуют автономно и не связаны друг с другом ${ }^{4}$.

Большинство радикальных и экстремистских идей проникают во Францию из-за рубежа, а точнее, через имамов. В 2002 г. Николя Саркози запретил въезд иностранных имамов во Францию по причине распространения ими экстремистских идей. По данным МВД, на середину нулевых годов из 1200 имамов три четверти не имели гражданства, а треть не владели французским языком. Поэтому государственная власть решила сама обучать имамов в собственной стране, причем среди предметов числятся как богословие, так и светские дисциплины [Нечитайло 2006: 169]. Особенно это стало актуально на фоне увеличивающегося числа этнических французов, принимающих ислам. Сегодня известно, что их число составляет около 50 тыс. чел. [Трофимова 2016: 65]. Из них около 1100 стали приверженцами радикального ислама, а около 5 тысяч симпатизируют его салафитской версии. Другим важным фактором стали взбудоражившие весь мир теракты 2015 г. против карикатуристов из журнала Charlie Hebdo, где важную роль сыграл самопровозглашенный имам, обративший террористов братьев Куаши в радикальный исламизм [Щегловин 2015].

Серьезная проблема, с которой столкнулась Франция, - это сращивание экстремизма и криминала. Экстремистские группировки активно распространяют свою идеологию в тюрьмах, и новообращенные заключенные начинают ненавидеть западную систему ценностей и верить в насилие как единственный способ достижения цели. Только в 2005 г. были созданы 175 радикальных исламистских ячеек в $89 \%$ французских тюрем. При этом $30 \%$ из них возникли спонтанно, а 20\% - под давлением сокамерников. Франция обратила внимание на эту проблему в середине 1990-х гг., когда все большее число бывших заключенных стали совершать теракты. Тогда были арестованы многие члены

1 GlobalTerrorismDatabase - France. 2020. URL: https://www.start.umd.edu/gtd/search/ Results.aspx? page $=5 \&$ search $=$ france $\&$ count $=100 \&$ expanded $=$ yes $\&$ charttype $=$ line $\&$ chart $=$ overt ime\&ob=CountryText\&od=asc\#results-table (accessed 10.07.2021).

2 Le terrorisme islamiste a fait 238 morts en France depuis janvier 2015. - LeMonde. 26.07.2016. Доступ: https://www.lemonde.fr/les-decodeurs/article/2016/07/26/le-terrorisme-islamiste-afait-236-morts-en-france-en-18-mois_4975000_4355770.html (проверено 09.07.2021).

3 By the numbers: France's battle against terror. - CBCNews. 12.12.2017. Доступ: https:// web.archive.org/web/20190404210321/https:/www.cbc.ca/news/thenational/national-todaynewsletter-terrorism-implant-registry-rice-1.4939071 (проверено 09.03.2021).

4 Французский политолог Тьерри Вольтон: «Исламизм - это вырождение ислама, его деградация». - Известия. 26.01.2006. Доступ: http://izvestia.ru/news/310517 (проверено 09.07.2021). 
радикальных исламистских группировок, а задача отслеживания и ликвидации террористических ячеек, созданных бывшими заключенными, была возложена на антитеррористическое ведомство. Все-таки, по мнению французского социолога Фархада Хосрохавара, системное решение проблемы не было предложено. Хотя во французских тюрьмах 50-80\% людей составляют мусульмане, имамы составляют всего 11\% служителей культа, работающих при тюрьмах. Государство ничего не делает для увеличения числа имамов, которые бы отвращали мусульман-заключенных от экстремизма, и тем самым предоставляет их экстремистским проповедникам [Нечитайло 2006: 172].

2015-2016 гг. стали годами особенно сильной активизации экстремистских сил в форме терроризма. В 2015 г. были убиты 12 журналистов сатирического журнала «Шарли Эбдо», произошло нападение на кошерные супермаркеты и серия взрывов в пригородах Парижа. Тогда впервые режим чрезвычайного положения был продлен до 3 месяцев вместо 12 дней. В июле 2016 г. тунисец, постоянно живший в Ницце, находясь за рулем грузовика, целенаправленно стал давить собравшихся людей на городской набережной, убил 86 человек и ранил свыше 430. В июле террористами был убит священник храма в г. СентЭтьене. Кроме того, в этот период обострилась проблема вербовки французских мусульман в террористические организации. По данным полиции, 15 тыс. французских граждан подозревались в терроризме, а 2 тыс. воевали на стороне террористов в Ираке и Сирии. По-прежнему остра проблема радикализма в тюрьмах, где в 2016 г. находилось около 1400 адептов экстремистских организаций. Попытки изолировать заключенных-экстремистов успеха не принесли, создание центра дерадикализации под Парижем в сентябре 2016 г. пока еще не привело к перелому ситуации, а некоторые прошедшие там обучение даже вернулись к экстремизму [Камкин 2018].

В 2020 г. во Франции произошла еще одна серия атак и нападений, связанных с исламским экстремизмом. В апреле в г. Роман-сюр-Изере исламист напал с ножом на прохожих из-за недовольства карантинными ограничениями. В октябре за карикатуру на пророка Мухаммеда в пригороде Парижа 18-летний чеченец обезглавил учителя истории, после чего последовали инциденты и теракты в Авиньоне, Ницце и Сартрувилле. При этом нападавшие не были членами экстремистских группировок. Все это означает, что французские мусульманские экстремисты чаще стали прибегать к насилию, действуя индивидуально. В ответ французское правительство ликвидировало турецкую экстремистскую группировку «Серые волки», готовившую нападения на курдов и армян и организовавшую уличные беспорядки с применением насилия в Вьенне и Дижоне [Плещунов 2020]. Кроме того, был депортирован 231 иностранный гражданин, обвиненный в пропаганде экстремизма, была распущена салафитская пропалестинская группировка «Шейх Ясин», а президент Э. Макрон вновь призвал к усилению государственного надзора за финансированием мечетей и подготовкой имамов [Шегловин 2020].

12 апреля 2021 г. сенат Франции двумя третями голосов утвердил в первом чтении законопроект о республиканских принципах, в значительной степени направленный именно на борьбу с исламским экстремизмом 1 . Документ

1 Однако Натали Крикорян-Дюронсуа, специалист по идеологической истории Франции, считает, что власти слишком поздно начали задумываться над решением проблемы экстремизма, потому что мусульманская община Франции, по-видимому, в значительной части уже находится в состоянии глубокого конфликта с государством. Например, после убийства учителя Самюэля Пати во всех школах Франции отдали ему почести, и при этом были зарегистрированы 793 инцидента неуважения к нему или отказа от участия в церемонии со стороны школьников, за что 44 были полностью, а 131 - на время исключены из школ. Это свидетельствует о бессилии системы школьного образования успешно сопротивляться экстремизму. 
состоит из 50 статей, охватывающих самые разные сферы жизни общества. Например, в нем важное место отводится борьбе с исламскими традициями, противоречащими французским нормам поведения, такими как многоженство и браки по принуждению, а также лишение дочерей наследства в пользу сыновей. Были приняты и статьи по ограничению нежелательной миграции; введены новые ограничения на ношение хиджаба и буркини (исламского купального костюма), особенно для несовершеннолетних. Законопроект также упростил порядок закрытия частных школ для мусульман; в институтах и университетах был введен полный запрет на любую практику, связанную с отправлением культа. Важной составляющей законопроекта стало усиление контроля государства над религиозными организациями. В частности, было предусмотрено обязательное включение в декларацию о доходах организаций сведений об иностранных пожертвованиях на сумму более 10 тыс. долл. ${ }^{1}$

Большинство этих мер ставит задачей принудить мусульманские общины к интеграции, следуя ассимиляционной модели, которая давно уже не устраивает тех, кто родился во Франции во втором или третьем поколении и продолжает испытывать на себе дискриминацию и расизм, особенно при приеме на работу, в процессе съема жилья и получения образования. Потому запрет выражать свою религиозную идентичность воспринимается как вызов и как ресурс противостояния «светскому», иначе - французскому обществу ${ }^{2}$. При этом религиозность принимает радикальную направленность, приобретая форму «неотрадиционализма» или «фундаментализма», т.е. становится своеобразным способом адаптации, заключающимся в «отказе от принимающего общества, его культуры и образа жизни, взамен которого идеализируются собственная страна и культура». Иными словами, речь идет о культурном радикализме, избавляющем от тяжелой необходимости согласовывать исламскую идентичность с какой-либо другой, т.к. основной принцип радикализма опирается на веру в то, что такое слияние не только невозможно, но и является предательством ислама [Waldmann 2010].

Таким образом, сегодня исламский экстремизм, ставший актуальной проблемой для многих западных стран, коренится не столько в успешной вербовке международных джихадистских организаций, сколько во внутренних проблемах, с которыми сталкивается в принимающей стране мусульманское население: это социально-экономические проблемы, запрет выражать свою исламскую идентичность, навязывание Западом своих ценностей, комплекс ущемленных в своих правах людей, негативное отношение европейцев.

На данный момент в западных национальных законодательствах нет единого устоявшегося определения экстремизма. Правовая неопределенность не является случайной: сложно найти баланс между охраной безопасности, борьбой с экстремизмом и нарушением прав человека. Хотя французский прези-

1 Сенат Франции утвердил в первом чтении законопроект о республиканских принципах. - Ш. 13.04.2021. Доступ: https://tass.ru/mezhdunarodnaya-panorama/11129585 (проверено 10.07.2021).

2 Особенно это становится актуальным в условиях более остро ощущаемой представителями второго и третьего поколения дискриминации, расизма и социальной несправедливости, последствий колониального прошлого (многие семьи алжирцев до сих пор воспитывают в своих детях ненависть к французской власти). При этом характер ислама всегда предполагал борьбу за свои права и находил отклик у угнетенных слоев. Достаточно вспомнить движение черных американцев в Америке, принявшее исламизированную форму, в начале $\mathrm{XX}$ в. Ислам помог им в т.ч. противопоставить себя белому американскому населению, традиционно находящемуся в рамках христианской культуры. Важным фактором здесь является «мирской» характер ислама, его политизированность, которые близки людям, борющимся за свои права и свободы. 
дент сделал оговорку, что борьба ведется не с исламом ${ }^{1}$, а с радикальными и экстремистскими исламистами, тем не менее законодательные инициативы свидетельствуют об ущемлении прав на свободное вероисповедание обычных мусульман.

\section{Список литературы}

Добаев И.П. 2002. Исламский радикализм: социально-философский анализ. Ростов н/Д: Изд-во СКНЦ ВШ. 120 с.

Камкин А.К. 2018. Радикальный исламизм в Германии и Франции: тенденции и вызовы. - Научно-аналитический вестник Института Европы РАН. № 6. C. $189-195$.

Наумкин В.В. 2006. Исламский радикализм в зеркале новых концепций. Восток (ORIENS). № 1. С. 5-24.

Нечитайло Д.А. 2006. Ислам во Франции. - Ближний Восток и современность. Вып. 36. С. 154-178.

Трофимова О.Е. 2016. Миграционные тенденции во Франции: новые реалии. - Франция на пороге перемен: экономика и политика в начале ХХІ века: сборник статей по итогам всероссийской научной конференции. С. 57-65.

Плещунов Ф.О. 2020. К вопросу о том, почему мусульмане Франции выбирают насилие как универсальный ответ на любую проблему. - Институт Ближнего Востока. 10.05. Доступ: http://www.iimes.ru/?p=74359 (проверено 12.05.2021).

Щегловин Ю.Б. 2015. Размышления о терактах во Франции. - Институт Ближнего Востока. 10.05. Доступ: http://www.iimes.ru/?p=23246 (проверено 12.05.2021).

Щегловин Ю.Б. 2020. Фактор борьбы с радикальным исламизмом в отношениях Франции с мусульманскими странами. - Институт Ближнего Востока.11.10. Доступ: http://www.iimes.ru/?p=73962 (проверено 12.05.2021).

Waldmann P. 2010. Radicalisation in the Diaspora: Why Muslims in the West Attack Their Host Countries. - Elcano Royal Institute. Working paper. Доступ: http://www. realinstitutoelcano.org/wps/wcm/connect/7042498041c1b790a471fee $151 \mathrm{fccd} 56 /$ WP9-2010_Waldmann_Radicalisation_Diaspora_Muslims_West.pdf?MOD=AJPE

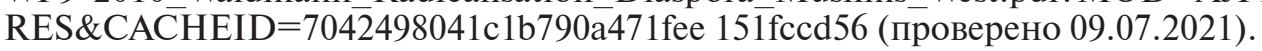

\footnotetext{
${ }^{1}$ Многие принципы сегодняшней политики в сфере безопасности не только французских властей, но и других стран ЕС были впервые сформулированы в знаменитой Мюнхенской речи премьер-министра Великобритании Д. Кэмерона в 2011 г. Он обозначил проблему сепаратизма и связал ее с кризисом идентичности, а исламистский экстремизм - с терроризмом, также предложил ввести либеральные критерии, по которым необходимо оценивать, насколько правомерна деятельность той или иной исламской ассоциации. При этом необходимо учитывать, что британская модель интеграции мигрантов коренным образом отличается от французской, как и общественные и экономические реалии жизни мусульманских общин. Таким образом, то, что Д. Кэмерон понимает под сепаратизмом мусульманских общин, и предлагаемые им меры по борьбе с ним, могут не подходить к французским реалиям. См.: URL: https://www.gov.uk/government/speeches/pms-speech-atmunich-security-conference). Текст стратегии Великобритании по борьбе с терроризмом см.: CONTEST. 2018. The United Kingdom's Strategy for Countering Terrorism. 20.08. URL: https://assets.publishing.service.gov.uk/government/uploads/system/uploads/attachment data/file/716907/140618_CCS207_CCS0218929798-1_CONTEST_3.0_WEB.pdf (accessed 10.07.2021).
} 
SAFONOVA Natalia Vyacheslavovna, Junior Researcher at the Institute of Oriental Studies, Russian Academy of Sciences (bld. 1, 12/1 Rozhdestvenka St, Moscow, Russia, 107031; safonovanat@gmail.com)

\section{THE PROBLEM OF ISLAMISM AND ISLAMIC EXTREMISM IN FRANCE}

Abstract. Such phenomena as Islamism and Islamic extremism relatively recently have emerged in France. Although several generations of Muslim migrants have already lived in the country, it has recently been that the number of terrorist attacks by Islamic extremists has increased. Most of the acts of violence were committed in the 2010s: unlike in previous years, they were organized not so much by international extremist movements as by French citizens. The main characteristics of Islamic extremism and the complex of related problems are considered within the framework of this article.

Keywords: Islamism, France, Islamic extremism, radical Islam 